JÓZSEF GYURÁCZ', ZOLTÁN LUKÁCS', PÉTER MOLNÁR', ZOLTÁN KOLLÁTH ${ }^{2,3}$

\title{
LIGHT AND TERRITORIALITY: A PRELIMINARY REPORT ON A CAPTURE-RECAPTURE STUDY OF COMMON BLACKBIRD (TURDUS MERULA)
}

\author{
${ }^{1}$ Eötvös Loránd University (ELTE) BDKP, Department Biology, Szom- \\ bathely, Hungary, ${ }^{2}$ Eötvös Loránd University (ELTE) BDKP, Department \\ of Physics, Szombathely, Hungary, ${ }^{3}$ Eszterházy Károly University, \\ Department of Physics, Eger, Hungary \\ E-mail: gyuracz.jozsef@sek.elte.hu
}

\begin{abstract}
The natural light conditions and the artificial lighting of the habitats affect the quality of bird territories and the territorial behaviour of birds. However, we know almost nothing about the evolutionary consequences of light on birds. In the biomonitoring part of the project entitled "Development of international research environment for light pollution studies", which is carried on in Bárdudvarnok in Somogy county, Hungary, we study the apparent survival probability, adaptive morphological characteristics and area fidelity in Common Blackbird populations living in territories under different light conditions. In this preliminary report, we also describe the methods of our studies - individual marking of birds, capture and recapture, measurement of body weight, wing length and other ecomorphological parameters - and the types of data collected. Based on the outcomes of the data collection planned to continue for several years, we can formulate proposals for the design and application of artificial lighting resulting in the reduction of the adverse effects of light pollution.
\end{abstract}

Keywords: Common Blackbird, light, light pollution, territory, capture-recapture 
GYURÁCZ JÓZSEF', LUKÁCS ZOLTÁN', MOLNÁR PÉTER', KOLLÁTH ZOLTÁN²,3

\title{
FÉNY ÉS TERRITORIALITÁS: ELŐZETES BESZÁMOLÓ EGY FEKETERIGÓ-POPULÁCIÓBAN (TURDUS MERULA) VÉGZETT FOGÁS-VISSZAFOGÁSON ALAPULÓ VIZSGÁLATRÓL
}

\begin{abstract}
${ }^{1}$ Eötvös Loránd Tudományegyetem (ELTE) BDPK Biológiai Tanszék, Szombathely, ${ }^{2}$ Eötvös Loránd Tudományegyetem (ELTE) BDPK Fizikai Tanszék, Szombathely, ${ }^{3}$ Eszterházy Károly Egyetem, Fizika Tanszék, Eger
\end{abstract}

\section{Összefoglalás}

Az élőhelyek természetes fényviszonyai és mesterséges éjszakai megvilágítása is hatással van a madarak territóriumainak minőségére és a madarak területvédő magatartásra is. Azonban a fény madarakra gyakorolt hatásának evolúciós következményeiről szinte semmit sem tudunk. A "Nemzetközi kutatási környezet kialakítása a fényszennyezés vizsgálatának területén" című projekt biomonitorozási területén, a Somogy megyei Bárdudvarnok község környezetében fészkelő feketerigó-populációban azt vizsgáljuk, hogy a különböző fényviszonyokkal rendelkező territórimokban fészkelő madarak látszólagos túlélési valószínűsége, adaptív morfológiai tulajdonságaik és területhűségük lényegesen különbözik-e egymástól. A madarak egyedi jelölésén, fogás-visszafogásán, testtömeg-, szárnyhossz- és egyéb ökomorfológai tulajdonságainak mérésén alapuló vizsgálataink módszereit, a gyűjtött adatok típusait is ismertetjük előzetes beszámolónkban. A több évre tervezett adatgyűjtés eredményei alapján javaslatokat tudunk megfogalmazni a fényforrások tervezéséhez, alkalmazáshoz és a fényszennyezés negatív hatásainak csökkentéséhez.

Kulcsszavak: fekete rigó, fény, territórium, fogás-visszafogás 


\section{Introduction}

Both natural and artificial light conditions affect the behaviour of birds. Based on the mechanism and consequence of artificial night lighting of suburbs and the countryside (night light pollution), direct and indirect adverse effects of light from artificial light sources (ALAN) on the living world can be divided into two groups. One of them is the so-called astronomical light pollution, where artificial illumination extinguishes the light of stars and other celestial bodies and thereby influences, for example, the behaviour of animals in such a way that their chances of survival are reduced. This can be observed in most parts of the Earth as the cumulative effect of many, many light sources. The other is called as ecological light pollution, where one or a few light sources may also affect the behaviour of individuals in a local animal population or influence the species dominance and spatial structure of a local community (LONGCORE AND $\mathrm{RICH}, 2004)$.

\section{The effect of light on the territorial behaviour of birds}

Birds compete for territories, available only in a limited amount in nature, which provide the environmental factors and resources they need to survive and reproduce. Moreover, they protect the occupied territories from other birds. Natural light conditions and artificial lighting of the habitats also affect the breeding and nesting of birds; therefore the areas illuminated to different degrees or in different ways also determine the quality of the territories. Some bird species avoid night-lit areas during the breeding season. If they can, they occupy territories (= an area used exclusively by an individual, protected from a competitor) in dark areas, that are offering equally good habitats for nesting.

Numerous studies in several songbird species demonstrated that artificial lighting ("constant daytime") disrupts the diurnal behaviour of birds, diurnal birds are also active at night, they sing and / or feed (DOMINONI and PARTECKE, 2015; RAAP et al., 2015). Males in illuminated areas sing and mate earlier, females paired with them lay their eggs earlier than their counterparts nesting in dark areas (Kempenaers et al., 2010). Laying eggs earlier resulted in larger clutch size (more eggs) according to some studies (FORESTER et al., 2006), however, nesters in areas illuminated by street lamps did not have a larger clutch size than those nested elsewhere. From this, it can be concluded that the illuminated nesting sites were neither of better quality nor more resource-rich in terms of bird productivity. A negative consequence of laying eggs earlier may also be that the hatching of the chicks will not be in sync with the abundance of food sources. The bird will need a large amount of food earlier than the peak date of the caterpillar or insect abundance (LAMBRECHTS et al., 1997). In artificially lit urban areas the nesting period of Common Blackbird (Turdus merula) begins a month earlier 
than in dark places outside the city. This can be both positive and negative for reproductive success (Dominnoni et al., 2013, DA SILVA et al., 2015). In illuminated areas, parent birds feed their chicks more intensively, which can increase fledging success, while it can reduce parental survival. Lighting at night decreases territorial aggressivity of birds. The poorer quality of the illuminated territories is indicated by the fact that in an English study, the European Robin's territorial singing and aggressivity decreased in an urban environment due to night lighting compared to those nesting in dark places (GILL, 2016). The effect of the spectrum of the light has also been studied on the nesting behaviour of the Great Tit (Parus major) and the European Pied Flycatcher (Ficedula hypoleuca) (DE JONGE et al., 2015). None of the investigated species occupied significantly less nesting territory in the areas illuminated with white, green, or red light compared to the dark areas.

In a study in Germany Dominoni et al. (2013) investigated the influence of the intensity of night lighting on the testes size and hormone (testosterone) production - which determine the reproduction of male birds - and on moult and locomotor activity of Common Blackbirds living in urban and rural environments. Birds from urban and rural habitats were kept in the same photoperiod (daily regular light and dark cycle), but half of the birds from each habitat was illuminated with a small amount (0.0001 lux) of light at night, this was the control group, and the other half with a large amount of light (0.3 lux). In the first year, the testes of males living in stronger night light reached the size typical of the reproductive period faster, about a month earlier than in the control group. Accordingly, their testosterone production started earlier. However, in the second year's reproductive cycle, the testes of male Blackbirds exposed to light pollution remained undeveloped, and their testosterone levels were low, while in the control group, testes and hormone production increased again by the reproductive period, according to regular photoperiodism. There was also a difference in the moult of the primary feathers, birds living in higher night lighting started moulting earlier but finished it more slowly than birds in the control group. There was no significant difference in the duration of daily locomotion between the control and experimental groups. According to the study, the observed differences in reproduction and moulting may have been mainly due to the fact that chronic light pollution was negative stress for Common Blackbirds. It is known that stress can reduce sexual activity and fertility in birds through the hypothalamus which regulates the gonads (CYR and ROMERO, 2007).

Light pollution also affects the mating choice of males with the territory (Kempenaers et al., 2010). Males, having territories at the edge of the forest, close to street lights, were twice as successful in obtaining extra-pair mates than their male counterparts nesting inside the forest or at a higher density. This was not just a simple edge effect because males nesting in dark edges were not more successful in extra-pair mating than their counterparts in the inner areas. 
Male success in extra relationship mating decreased exponentially as a function of the distance from the lamps. In the illuminated areas, males are singing earlier. Already paired females, inspired by the early song leave their nests in the early morning hours and mate with the early singing males. The age of males is also an essential factor in the mating choice. Adult male Eurasian Blue Tits are more likely to choose a new pair than younger ones (DelHeY et al. 2006). Adult male specimens of the Blue Tit (Cyanistes ceruleus) begin singing earlier in the morning than young males, and therefore, extra-pair mating is more common among them (Poesel et al. 2006). Artificial lighting increases the success of extra-pair mating both in adult and young males, but this effect is significantly greater in the young. Young males nesting in dark areas usually do not choose another pair, but when the territory is illuminated, they mate with another female in the same way as adult males nesting in a dark place. This may also suggest that the better quality, dominant males occupy the illuminated sites, but this has not been supported by previous research. Males of the illuminated sites were not older, larger in size or in better condition than their counterparts nesting in the dark. Pairs of males nesting near the lamps were just as likely to mate with other males as pairs of males nesting elsewhere. Pairs of males nesting in border areas were less likely to mate with other males, but this could only be because there were fewer neighbouring nesters (fewer occasions, local density effect). The clutch size and reproductive success of females mating with males occupying territory in light-polluted areas were no greater than that of their counterparts nesting elsewhere. The greater success of males nesting in light-polluted areas in extra-pair mating was probably due to their earlier-started singing, as this may have been more attractive to females (Kempenaers et al. 1992, Dolan et al. 2007, CockBurn et al. 2009, SUter et al. 2009). Thus, light pollution changes the mating strategy of females, through the earlier-started singing of males, but this does not mean greater adaptability for them.

Owning the territory comes at a cost and also benefit to the bird. The benefits are clear, as the individual has access to resources, meaning that he or she and his chicks will have a better chance of survival and reproduction (fitness). The cost is also well measurable, boundaries need to be marked, and the territory needs to be protected, rival individuals need to be kept away, which can reduce fitness. Territorial behaviour will only persist in the longer term if the benefits outweigh the costs. Studies have clearly shown that the lighting conditions of territories and light pollution affect the behaviour of birds, but it was also admitted that we know almost nothing about the fitness-modifying effects of these changes, i.e. about their evolutionary consequences. The males of songbirds not only compete for nesting territories, but most of them are likely to return to once-proven nesting sites year after year (philopatry, area loyalty). From the point of view of reproductive success, the best quality places are presumably occupied by the strongest, heavier, larger body size, dominant males as early as possible in the spring. 


\section{Goals of the study}

Based on the results discussed in the previous chapter, we formulated the following questions $(\mathrm{Q})$ and hypotheses $(\mathrm{H})$ regarding the relationship between the light conditions influencing the quality of territories and territoriality:

1. Q. Are nesting sites that are richer in night light but not significantly different in other environmental conditions (e.g., noise pollution) occupied by subdominant individuals of lower body weight and body size?

1. $\mathrm{H}$. If light pollution is detrimental to the fitness of breeding birds, we assume that there is a competition for darker places at night, i.e., birds occupying darker areas have higher average body weight, wing length, and better condition than nesters in less dark areas.

2. Q. Are birds occupying light-contaminated but otherwise in other environmental factors similar territories less likely to survive than birds nesting in darker areas?

2. H. If light pollution is detrimental to the survival of breeding birds because they feed their chicks longer, then we assume that birds that nest in less dark areas live shorter than their counterparts that nest in darker places at night.

3. Q. Is nesting site fidelity of birds occupying light-polluted but otherwise in other environmental factors similar territories lower than that of birds nesting in darker areas?

3. $\mathrm{H}$. If light pollution is detrimental to the survival of breeding birds because they feed their chicks longer, then we assume that birds nesting in lighter areas will return to the same territory in the next nesting period in a lower rate, i.e. their nesting site fidelity is lower than that of birds nesting in darker areas.

The Common Blackbird is a relatively large-bodied, widespread, common and territorial songbird, available in large numbers, and therefore it is suitable for studying the relationship between light and territoriality. We already have experience on the age, sex and body size dependence of the spatial distribution of our model bird species (OrBán et al. 2019).

The aim of our study is to collect data based on a Common Blackbird nesting population to answer the above questions, to test hypotheses related to them, and thus to demonstrate the role of light in the territoriality and nesting site fidelity of birds. This requires in situ, long-term and systematic research.

\section{Materials and methods}

\section{Study area and measurement of light at the nesting sites}

Capture and measurement of the birds are carried out in the biomonitoring area of the project entitled "Development of international research environment for light pollution studies", in the vicinity of the village of Bárdudvarnok. 
Bárdudvarnok is located in Zselic, in Southern Transdanubia, where many wooded, bushy habitats offer nesting sites for the Common Blackbird. Light measurements at breeding sites were performed according to our standard method used for the light pollution survey in the Hungarian national parks ( KolLÁTH et al. 2020a). The RGB colour and radiance information from the images of calibrated digital cameras provides essential information on the light level. The resulting radiance maps of the upper hemisphere provides the full information about the local light fields. The metrological system for the measurements is defined by KollÁTH et al. (2020b). Since the light condition at a given place varies in a short time scale due to the changes in weather conditions, Moon phases, etc., it is crucial to perform constant monitoring. A nearby allsky monitoring station provides supplementary information. The information about the shielding of the foliage together with the possible night conditions and the distance from the local sources provide the bases for local light field modelling. The details of this process will be published elsewhere.

\section{Capture and measurements}

Bird ringing was conducted during breeding seasons, from the end of March to the end of July. For bird capture, mist-nets (12-meter-long and 2.5-meter-high with 5 shelves and a mesh size of $16 \mathrm{~mm}$ ) were used. When using the bird-call tones, strict rules are applied to minimize the disturbance of the birds. Bird-call tones can be used only for a maximum of half an hour in a territory during one ringing attempt, and the mist-net is left open only for a maximum of 2 hours. If the birds (both male and female) are not caught during this time, they will be tried to catch again after 5-7 days. Within one year and one territory, only maximum of 3 attempts will be made to capture the bird. If the capture is unsuccessful three times, the bird is considered to be identified without capture within the territory.

All birds were marked by aluminium and colour rings (Figure 1.), aged and sexed, according to SvEnsSON (1992). Biometric measurements were taken using the methods of Actio Hungarica (SzEnTEndrey et al., 1979). All birds were weighed to the nearest $0.1 \mathrm{~g}$ (using a spring balance). The bill, skull, tarsus, wing and third primary length were measured to the nearest $1 \mathrm{~mm}$. The fat reserves were estimated visually according to BusSE and MEISSNER (2015) ranging from 0 (no fat) to 8 (bulging fat). After ringing and measurement, the captured birds are released at the capture site and then observed to see if the bird returns to its territory. 1-5 days after each ringing, using binoculars, we re-check the territories we had previously captured and thus marked birds with coloured rings. By recapturing ringed birds in the years following the year of ringing or by observing them with binoculars, we can determine whether or not they are re-occupying the same territory they were ringed in or one near to it. If the recaptured or observed bird was located in the immediate vicinity of the pre- 
vious year's territory (within 0-15 meters), then it was considered as another nesting in the previous year's territory (territory-faithful bird).

If in the year following the ringing, the bird returns between the territory of the previous year nesting and the territory in its immediate vicinity, then the bird's nesting in the current year was recorded in the nearest territory (the shortest linear distance was measured).

We considered that the bird left the previous year's territory if the bird did not occupy an area within 0-15 meters of the nesting territory of the previous year again in the following year (MÁtral et al. 2012).

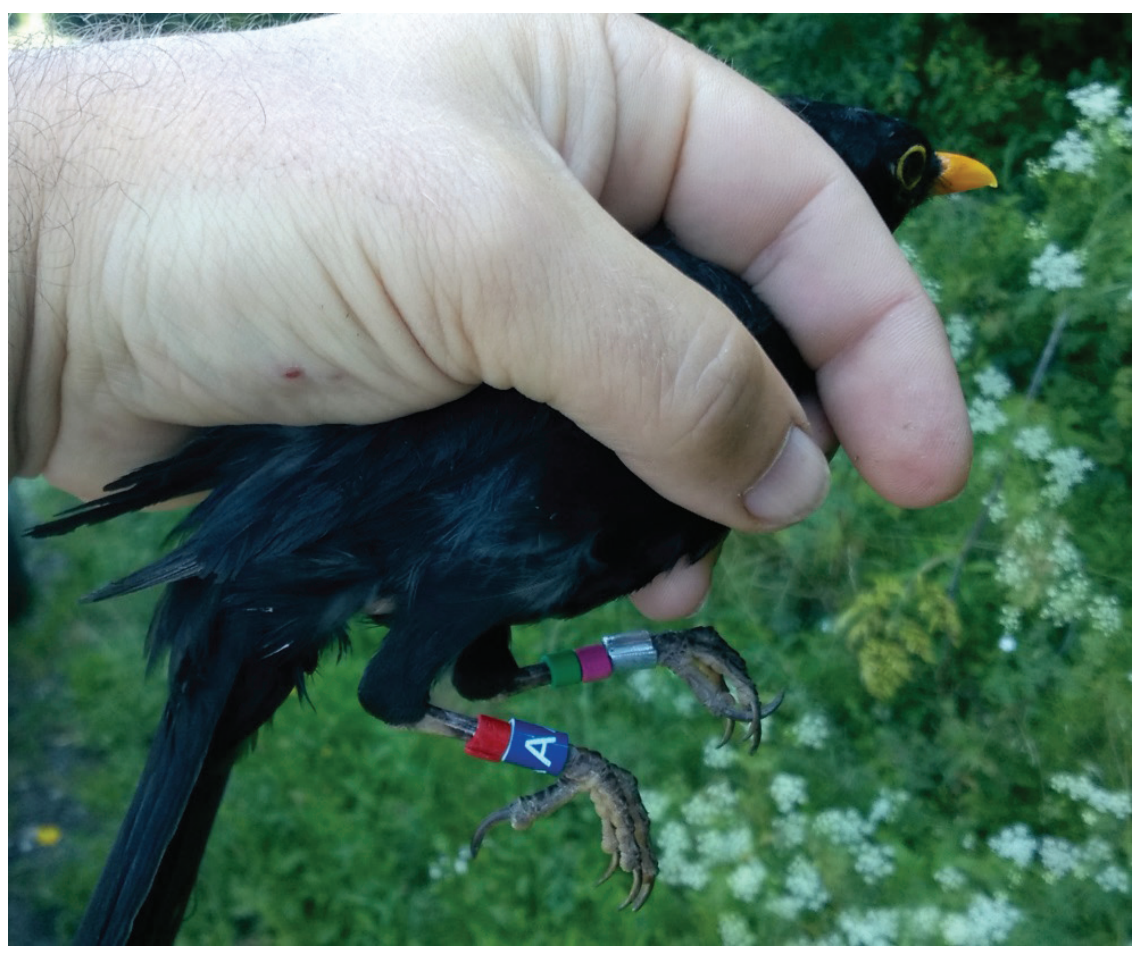

Figure 1. Adult male specimen of Common Blackbird (Turdus merula) marked with a combination of aluminium and coloured plastic rings. 27th July of 2018. Bárdudvarnok

\section{Determination of territorial fidelity}

If we have a sufficient number of ringed and recaptured birds, we can calculate territorial fidelity, which is characteristic for the population and also for the habitat, based on the following method (Mátral et al. 2012). In the study area, the loyalty of adult birds to the nesting area is examined based on the total number of ringed individuals and the number of recaptured birds. As a first step, the proportion of recapture of the ringed birds in the study area: 
[recapture rate $(\%)=($ number of adult birds recaptured $/$ total number of adult birds ringed) $\times 100]$;

then the recapture rate by sex is examined as well.

Further studies will be performed using the MARK 7.1 (WHITE and BURNHAM, 1999) software package to determine the probability that a bird will be caught alive next year (F) and test the likelihood of fidelity ( $p)$. The calculations use the "Joint live encounter \& dead recovery (d).

In the course of the analyses (depending on the sample size), territories of adult male and female birds which returned there in the following years after the initial ringing are examined (MÁTRAl et al., 2012). The returning bird considered loyal to the territory if it occupies a territory in the immediate vicinity (0-15 $\mathrm{m}$ ) of its last-year territory. In all other cases, the bird is considered as a dispersing bird, which means it left its previous-year territory. If a bird is detected in more than one territory within the study area in the same year, then that territory will be considered as its nesting territory for that year in which it is most often observed and / or in which it sings most often. We also examine whether at the first detection of the bird next year's return was there already another singing male in the bird's previous year's territory.

We calculate the rate of territorial fidelity in the case that the bird's territory from the previous year is already occupied when the bird returns, as well as if it is free. The same is calculated for dispersing birds. Chi-square test is used for statistical analyzes. We use Google Earth 6.1.0.5001 (http://www.google.com/ earth/index.html) and Quantum GIS 1.6.0 (www.qgis.org) software packages to create maps and measure distances.

\section{Results}

Light metering data characteristic for Common Blackbird nesting areas are demonstrated in Figure 2. The light field at a given location depends mostly on the shielding effect of the foliage and the distance and number of local light sources. The horizontal illumination resulted from the diffuse light of the sky is about 1.5-2.0 mlx on cloudless and moonless nights at open places. The illumination can be reduced to a few tenths of millilux under the foliage. In contrary, the vertical illumination due to the direct light from the sources can reach $1 \mathrm{Ix}$, depending on the distance from the source. 

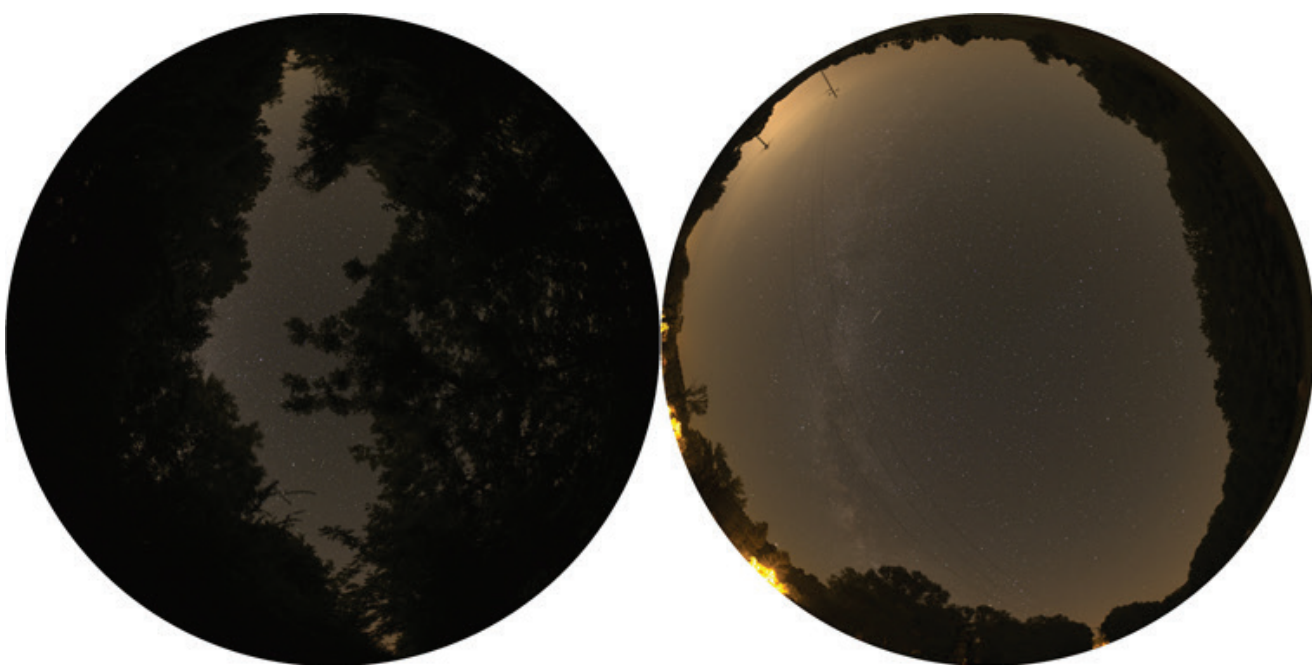

Figure 2. Comparison of the light characteristics of a shielded (left) and an open (right) location during a moonless and cloudless night.

Data on Common Blackbirds ringed in the 2018 and 2019 nesting season are shown in Table 1. The numbered aluminium ring was placed on the left leg of the bird, the blue plastic ring with the letter " $A$ " was placed on the right leg of the bird, and the coloured plastic rings without the letter were placed on the left or right leg of the bird in different colour combinations.

age: 1 = juvenilis, 2 = second year adult, 2+ = after second year adult; sex: $M=$ male, $F=$ female

\begin{tabular}{|c|c|c|c|c|c|c|c|c|c|c|c|}
\hline $\begin{array}{l}\text { Ring num- } \\
\text { ber Colour } \\
\text { ring }\end{array}$ & Colour ring & Age & Sex & $\begin{array}{l}\text { Fat } \\
\text { score }\end{array}$ & $\begin{array}{l}\text { Skull } \\
\mathrm{mm}\end{array}$ & $\begin{array}{l}\text { Bill } \\
\mathrm{mm}\end{array}$ & $\begin{array}{l}\text { 3.pr. } \\
\text { mm }\end{array}$ & $\begin{array}{l}\text { Wing } \\
\mathrm{mm}\end{array}$ & $\begin{array}{l}\text { Tail } \\
\mathrm{mm}\end{array}$ & $\begin{array}{l}\text { Tarsus } \\
\mathrm{mm}\end{array}$ & $\begin{array}{l}\text { Body } \\
\text { mass } \\
g\end{array}$ \\
\hline 213626 & blueA & $2+$ & $M$ & 2 & 52.8 & 16.5 & 94 & 125 & 99 & 34.4 & 85.5 \\
\hline 213627 & $\begin{array}{l}\text { blueA } \\
\text { green }\end{array}$ & $2+$ & $M$ & 0 & 52.4 & 16.2 & 96 & 126 & 108 & 32.1 & 75.5 \\
\hline 219629 & blueA pink & $2+$ & $\mathrm{F}$ & 1 & 51.7 & 16.0 & 93 & 122 & 99 & 32.4 & 96.5 \\
\hline 213630 & blueA red & $2+$ & M & 1 & 51.4 & 16.5 & 95 & 123 & 100 & 33.0 & 82.0 \\
\hline 213631 & $\begin{array}{l}\text { blueA } \\
\text { yellow }\end{array}$ & $2+$ & $M$ & 1 & 53.4 & 15.8 & 97 & 127 & 109 & 34.0 & 83.0 \\
\hline 213632 & blueA white & $2+$ & M & 1 & 52.4 & 16.3 & 99 & 129 & 110 & 33.9 & 81.5 \\
\hline $\begin{array}{l}\text { green } \\
213635\end{array}$ & blueA & 2 & $M$ & 0 & 52.4 & 16.3 & 95 & 122 & 102 & 32.9 & 76.0 \\
\hline $\begin{array}{l}\text { green } \\
222302\end{array}$ & $\begin{array}{l}\text { green } \\
\text { blueA }\end{array}$ & $2+$ & $M$ & 1 & 53.5 & 16.9 & 98 & 127 & 109 & 32.8 & 86.0 \\
\hline $\begin{array}{l}\text { green } \\
222303\end{array}$ & pink blueA & $2+$ & $\mathrm{F}$ & 0 & 51.3 & 16.1 & 95 & 124 & 105 & 33.3 & 79.0 \\
\hline red 222304 & $\begin{array}{l}\text { green } \\
\text { blueA }\end{array}$ & 2 & $M$ & 2 & 51.2 & 15.4 & 92 & 121 & 99 & 32.3 & 84.0 \\
\hline
\end{tabular}




\begin{tabular}{|c|c|c|c|c|c|c|c|c|c|c|c|}
\hline $\begin{array}{l}\text { green } \\
226292\end{array}$ & $\begin{array}{l}\text { yellow } \\
\text { blueA }\end{array}$ & $2+$ & M & 0 & 51.2 & 16.2 & 100 & 130 & 110 & 31.6 & 70.0 \\
\hline $\begin{array}{l}\text { green } \\
226295\end{array}$ & white blueA & 2 & M & 1 & 51.7 & 16.2 & 94 & 123 & 100 & 33.3 & 85.0 \\
\hline $\begin{array}{l}\text { green green } \\
226296\end{array}$ & blueA & $2+$ & $M$ & 0 & 52.6 & 16.3 & 97 & 125 & 105 & 32.7 & 77.5 \\
\hline $\begin{array}{l}\text { green green } \\
226297\end{array}$ & $\begin{array}{l}\text { green } \\
\text { blueA }\end{array}$ & $2+$ & $M$ & 1 & 51.1 & 16.7 & 94 & 123 & 105 & 31.3 & 73.0 \\
\hline $\begin{array}{l}\text { green green } \\
229226\end{array}$ & pink blueA & $2+$ & $M$ & 0 & 52.1 & 16.3 & 95 & 124 & 105 & 33.4 & 82.0 \\
\hline $\begin{array}{l}\text { green green } \\
229227\end{array}$ & red blueA & $2+$ & M & 1 & 52.2 & 16.9 & 95 & 123 & 105 & 33.7 & 83.0 \\
\hline $\begin{array}{l}\text { green green } \\
229228\end{array}$ & $\begin{array}{l}\text { yellow } \\
\text { blueA }\end{array}$ & $2+$ & M & 1 & 53.4 & 17.7 & 97 & 127 & 107 & 34.0 & 82.0 \\
\hline $\begin{array}{l}\text { green green } \\
229229\end{array}$ & white blueA & 2 & M & 1 & 57.7 & 16.0 & 96 & 122 & 100 & 31.6 & 80.0 \\
\hline $\begin{array}{l}\text { green pink } \\
229231\end{array}$ & blueA & $2+$ & M & 0 & 51.1 & 16.7 & 94 & 122 & 105 & 32.5 & 73.0 \\
\hline $\begin{array}{l}\text { green pink } \\
229239\end{array}$ & $\begin{array}{l}\text { green } \\
\text { blueA }\end{array}$ & $2+$ & M & 0 & 53.1 & 16.2 & 98 & 129 & 109 & 32.8 & 82.5 \\
\hline $\begin{array}{l}\text { green pink } \\
229240\end{array}$ & pink blueA & $2+$ & M & 0 & 49.3 & 15.7 & 96 & 122 & 104 & 31.8 & 75.0 \\
\hline $\begin{array}{l}\text { green } \\
234019\end{array}$ & red blueA & $2+$ & $\mathrm{F}$ & 0 & 51.1 & 16.7 & 96 & 123 & 101 & 32.7 & 83.0 \\
\hline $\begin{array}{l}\text { green yellow } \\
229250\end{array}$ & $\begin{array}{l}\text { red } \\
\text { blueA }\end{array}$ & $2+$ & $M$ & 0 & 52.0 & 16.1 & 98 & 127 & 110 & 34.1 & 87.0 \\
\hline $\begin{array}{l}\text { green pink } \\
234020\end{array}$ & $\begin{array}{l}\text { yellow } \\
\text { blueA }\end{array}$ & 1 & $\mathrm{~F}$ & 0 & 51.2 & 15.1 & 93 & 121 & 105 & 33.8 & 83.5 \\
\hline $\begin{array}{l}\text { green pink } \\
234021\end{array}$ & white blueA & $2+$ & $M$ & 0 & 52.3 & 16.6 & 97 & 124 & 106 & 33.6 & 83.0 \\
\hline $\begin{array}{l}\text { yellow red } \\
234075\end{array}$ & white blueA & 2 & $M$ & 4 & 51.6 & 14.9 & 97 & 124 & 99 & 33.6 & 83.0 \\
\hline pink 234078 & blueA & $2+$ & $M$ & 1 & 51.5 & 16.5 & 96 & 125 & 105 & 32.9 & 77.5 \\
\hline red 234080 & blueA & $2+$ & M & 2 & 50.7 & 16.9 & 95 & 124 & 100 & 32.1 & 78.0 \\
\hline $\begin{array}{l}\text { white } \\
234081\end{array}$ & blueA & $2+$ & M & 0 & 51.6 & 17.4 & 98 & 126 & 107 & 31.3 & 82.5 \\
\hline $\begin{array}{l}\text { yellow } \\
234085\end{array}$ & blueA & $2+$ & M & 0 & 50.6 & 14.9 & 96 & 123 & 105 & 32.7 & 82.5 \\
\hline $\begin{array}{l}\text { green red } \\
234086\end{array}$ & blueA & 1 & $\mathrm{~F}$ & 0 & 47.7 & 14.7 & 92 & 120 & 98 & 30.5 & 79.0 \\
\hline
\end{tabular}

Table 1. Age, sex and biometric data of Common Blackbirds captured in Bárdudvarnok 


\begin{tabular}{|c|c|c|c|c|c|}
\hline $\begin{array}{l}\text { Ring number } \\
\text { Colour ring }\end{array}$ & Colour ring & Age & Sex & Fat score & $\begin{array}{l}\text { Body mass } \\
\mathrm{g}\end{array}$ \\
\hline 213632 & blueA white & $2+$ & $M$ & 0 & 79.0 \\
\hline $\begin{array}{l}\text { green green } \\
229227\end{array}$ & red blueA & $2+$ & M & 0 & 85.0 \\
\hline $\begin{array}{l}\text { green green } \\
226297\end{array}$ & green blueA & $2+$ & $M$ & 0 & 72.0 \\
\hline $\begin{array}{l}\text { green pink } \\
229240\end{array}$ & pink blueA & $2+$ & $M$ & 0 & 75.0 \\
\hline 213631 & blueA yellow & $2+$ & $M$ & 1 & 82.0 \\
\hline $\begin{array}{l}\text { yellow } \\
234085\end{array}$ & blueA & $2+$ & M & 0 & 80.0 \\
\hline
\end{tabular}

Table 2. Age, sex and biometric data of Common Blackbirds recaptured in Bárdudvarnok See abbreviations at Table 1.

\section{Conclusions}

Based on our previous nationwide studies on several songbird species (KIss et al. 2020), we can conclude that data on ringed and recaptured Common Blackbird in Bárdudvarnok are suitable for establishing age-, sex- and territory-dependent survival, capture and territorial fidelity probabilities. However, the number of birds marked in the two nesting periods, which was strongly influenced by the bad weather conditions in 2019, does not currently provide a representative sample for statistical analyzes. Bird ringing during at least one nesting period and in good weather conditions, as well as further re-checking of the ringed birds, are required to analyze the assumed relationship between the light conditions of the site and the adaptive characteristics of the birds occupying the site and their territorial fidelity by statistical methods.

As a result of the study, we expect to be able to clarify the putative role of light and illumination in the survival of birds, in territorial behaviour, that are important for the evolution of bird populations, and in shaping related adaptive morphological features.

Based on the results, we can make recommendations for the design and application of light sources and for reduction of the adverse effects of light pollution.

\section{Acknowledgement}

The project is supported by the European Union and co-financed by the European Social Fund (Grant no. EFOP-3.6.2- 16-2017-00014; Development of international research environment for light pollution studies). 


\section{References}

Busse, P., Meissner, W. (2015). Bird Station Manual. SE European Bird Migration Network, Bird Migration Research Station, University of Gdansk, Gdansk.

Cockburn, A., Dalziell, A. H., Blackmore, C. J., Double, M. C., Kokko, H., Osmond, H. L., BeCK, N. R., Head, M. L., Wells, K. (2009). Superb fairy-wren males aggregate into hidden leks to solicit extragroup fertilizations before dawn. Behavioral Ecology, 20(3), 501-510. DOI: https://doi.org/10.1093/beheco/arp024.

CYR, N. E., Romero, M. (2007). Chronic stress in free-living European starlings reduces corticosterone concentrations and reproductive success. General and Comparative Endocrinology 151, 82-89. DOI: https://doi. org/10.1016/j.ygcen.2006.12.003

Da Silva, A., Valcu, M., Kempenaers, B. (2015). Light pollution alters the phenology of dawn and dusk singing in common European songbirds. Philosophical Transactions of the Royal Society B, 370. 20140126. DOI: https://doi.org/10.1098/ rstb.2014.0126

Delhey, K., Peters, A., Johnsen, A., Kempenaers, B. (2006). Fertilization success and UV ornamentation in blue tits Cyanistes caeruleus: Correlational and experimental evidence. Behavior Ecology, 18, 399-409. DOI: https://doi. org/10.1093/beheco/arl096

Dolan, A. C., Murphy, M. T., Redmond, L. J., Sexton, K., Duffield, D. (2007). Extra-pair paternity and the opportunity for sexual selection in a socially monogamous passerine. Behavioral Ecology, 18(6), 985-993. DOl: https://doi.org/10.1093/ beheco/arm068

Dominoni, D., PARTECKE, J. (2015). Does light pollution alter the perception of daylength? A test using light loggers on European blackbirds (Turdus merula). Philosophical Transactions of the Royal Society B 370. 1667. DOI: https:// doi.org/10.1098/rstb.2014.0118

Dominoni, D. M., Quetting, M., PARTeCKE, J. (2013). Long-Term Effects of Chronic Light Pollution on Seasonal Functions of European Blackbirds (Turdus merula). PLOS ONE 8 (12). e85069. DOI: https://doi.org/10.1371/journal.pone.0085069

deJonge, M., Quyang, J. Q., da Silva, A., van Grunsven, R. H. A., Kempenaers, B. Visser, M. E., SPOelSTRA, K. (2015). Effects of nocturnal illumination on life-history decisions and fitness in two wild songbird species. Philosophical Transactions of the Royal Society B, 370, 20140128. DOI: https://doi.org/10.1098/rstb.2014.0128

Foerster, K., Valcu, M., Johnsen, A. Kempenaers, B. (2006). A spatial genetic structure and effects of relatedness on mate choice in a wild bird population. Molecular Ecology, 15: 4555-4567. DOI: https://doi.org/10.1111/j.1365294X.2006.03091.X 
GILL, V. (2016). Light pollution dampens urban robins' song. BBC News. Science \& Environment. https://www.bbc.com/news/science-environment-38317255

Kempenaers, B. Verheyen, G. R., Van den Broeck, M., Burke, T., Van Broeckhoven, C. DHondt, A. A. (1992). Extra-pair paternity results from female preference for high-quality males in the blue tit. Nature, 357, 494-496.

Kempenaers, B., Borgström, P., Loes, P., Schlicht, E., Valcu, M. (2010). Artificial Night Lighting Affects Dawn Song, Extra-Pair Siring Success, and Lay Date in Songbirds. Current Biology, 20. 1735-1739. DOI: https://doi.org/10.1016/j. cub.2010.08.028

Kolláth, Z., Jechow, A, Cool, A. Kolláth, K. Száz, D. Tong, K. P. (2020). Introducing the Dark Sky Unit for multi-spectral measurement of the night sky quality with commercial digital cameras. Journal of Quantitative Spectroscopy and Radiative Transfer, 253, 107162. DOI: https://doi.org/10.1016/j.jqsrt.2020.107162

Kolláth, Z., Száz, D., Tong, K. P., Kolláth, K. VanYó, J. (2021). Light Pollution Survey in Hungarian National Parks. In this volume. Acta Universitatis de Carolo Eszterházy Nominatae Sectio Biologiae in press

Lambrechts, M. M., Blondel, J., Maistre, M., \& Perret, P. (1997). A single response mechanism is responsible for evolutionary adaptive variation in a bird's laying date. Proceedings of the National Academy of Sciences of the United States of America, 94(10), 5153-5155. DOI: https://doi.org/10.1073/ pnas.94.10.5153

LongCoRE, T. RicH, C. (2004). Ecological light pollution. Frontiers in Ecology and the Environment, 2(4), 191-198. DOI: 10.1890/1540-9295(2004)002[0191:ELP] 2.0.CO;2

Kiss, Cs., Molnár P., Karcza, Zs., LukÁCs, K. O., WinkLer, D., Gyurácz, J. (2020). Study of apparent survival and capture probabilities of some passerines in Hungary. North-western Journal of Zoology. 16(1), 78-83.

Mátral, N., Gyurácz, J., Lenczl, M., Hoffmann, Gy., Bakonyı, G., Mátics, R. (2012). Philopatry analysis of the great reed warbler (Acrocephalus arundinaceus) based on ringing data in Europe. Biologia Section Zoology 67(3), 596-601. DOI: https://doi.org/10.2478/s11756-012-0043-8.

Orbán, L., Lovász, L., LuKÁcs, Z., GyuRÁcz, J. (2019). Age-, sex- and size-related spatial distribution in the common blackbird (Turdus merula) during the postfledging period. North-western. Journal of Zoology 15(1). 84-90.

Poesel, A., Kunc, H. P., Foerster, K., Johnsen, A., Kempenaers, B. (2006). Early birds are sexy: Male age, dawn song and extra-pair paternity in blue tits Cyanistes (formerly Parus) caeruleus. Animal Behavior 72. 531-538.

Suter, S. M., Ermacora, D., Rieille, N., Meyer, D. R. (2009). A distinct reed bunting dawn song and its relation to extra-pair paternity. Animal Behavior 77. pp. 473-480. 
Svensson, L. (1992). Identification Guide to European Passerines. $4^{\text {th }}$ ed. Ugga, Stockholm.

SzentendRey, G., Lövel, G. Kállay, Gy. (1979). Az "Actio Hungarica” madárgyűrűző tábor mérési módszerei. [Measuring methods in the bird ringing camps of Actio Hungarica] Állattani Közlemények 66, 161-166. (in Hungarian)

RaAp, T., Pinxten, R. Eens, M. (2015). Light pollution disrupts sleep in free-living animals. Scientific Report 5, 13557.

White, G. C., Burnham, K. P. (1999). Program MARK: survival estimation from populations of marked animals. Bird Study, 46, 120-138. 